\title{
Desulfotomaculum hydrothermale sp. nov., a thermophilic sulfate-reducing bacterium isolated from a terrestrial Tunisian hot spring
}

\author{
Olfa Haouari, ${ }^{1,2}$ Marie-Laure Fardeau, ${ }^{1}$ Jean-Luc Cayol, ${ }^{1}$ Corinne Casiot, $^{3}$ \\ Françoise Elbaz-Poulichet, ${ }^{3}$ Moktar Hamdi, $^{2}$ Manon Joseph ${ }^{1}$ \\ and Bernard Ollivier ${ }^{1}$
}

Correspondence Bernard Ollivier bernard.ollivier@univmed.fr

\author{
${ }^{1}$ IRD, UMR 180, Microbiologie et Biotechnologie des Environnements Chauds, IFR-BAIM, ESIL, \\ Universités de Provence et de la Méditerranée, 163 Avenue de Luminy, F-13288 Marseille Cedex \\ 09, France \\ ${ }^{2}$ Laboratoire d'Écologie et de Technologie Microbiennes INSAT, 1080 Tunis, Tunisia \\ ${ }^{3}$ Laboratoire Hydrosciences Montpellier, UMR 5569, Universités Montpellier 2 et 1, CNRS, IRD, \\ Place E. Bataillon, Case MSE, 34095 Montpellier Cedex 05, France
}

\begin{abstract}
A novel strictly anaerobic, moderately thermophilic, sulfate-reducing bacterium, designated strain Lam $5^{\top}$, was isolated from a hot spring in north-east Tunisia and was characterized phenotypically and phylogenetically. The isolate stained Gram-negative but had a Gram-positive-type cell wall. The strain comprised endospore-forming, slightly curved rod-shaped cells with peritrichous flagella. It did not possess desulfoviridin. Strain Lam $5^{\top}$ grew anaerobically at $40-60{ }^{\circ} \mathrm{C}$ (optimally at $55{ }^{\circ} \mathrm{C}$ ) and at $\mathrm{pH}$ 5.8-8.2 (optimally at $\mathrm{pH} 7.1$ ); it did not require $\mathrm{NaCl}$ but tolerated concentrations up to $1.5 \%(\mathrm{w} / \mathrm{v})$. It utilized lactate, pyruvate, formate, ethanol, butanol, glycerol, propanol and $\mathrm{H}_{2}$ (plus acetate) as electron donors. Lactate was oxidized and pyruvate was fermented to acetate. Sulfate, sulfite, thiosulfate, $\mathrm{As}(\mathrm{V})$ and $\mathrm{Fe}(\mathrm{III})$ (but not elemental sulfur, fumarate, nitrate or nitrite) were used as electron acceptors. The $\mathrm{G}+\mathrm{C}$ content of the genomic DNA was 46.8 mol\%. Phylogenetic analysis based on 16S rRNA gene sequencing showed that strain Lam5 ${ }^{\top}$ was a member of the genus Desulfotomaculum, with Desulfotomaculum putei as its closest relative (96\% similarity to the type strain). On the basis of genotypic, phenotypic and phylogenetic data, strain Lam5 ${ }^{\top}$ represents a novel species of the genus Desulfotomaculum, for which the name Desulfotomaculum hydrothermale sp. nov. is proposed. The type strain is Lam5 ${ }^{\top}$ $\left(=\right.$ DSM $18033^{\top}=$ JCM $\left.13992^{\top}\right)$.
\end{abstract}

Micro-organisms associated with hot springs in geothermal areas have attracted considerable interest in recent years. Because the primary production in these extreme environments is probably sustained by hydrogen-oxidizing bacteria, special attention has been paid to the microaerophilic members of the order Aquificales (Aguiar et al., 2004), which are recognized as dominant hydrogen oxidizers within terrestrial hot springs (Reysenbach et al., 1994; Hugenholtz et al., 1998; Reysenbach \& Shock, 2002). In addition to hydrogen oxidation performed under microaerophilic conditions by members of the Aquificales, hydrogen oxidation occurring under anaerobiosis is also important in hot springs, as temperature and sulfide

\section{Abbreviation: SRB, sulfate-reducing bacteria.}

The GenBank/EMBL/DDBJ accession numbers for the 16S rRNA gene sequences of strains Lam5 ${ }^{\top}$ and Lam7 are EF081293 and EF494253, respectively. concentrations can be involved in maintaining a low redox potential in situ. Under these physicochemical conditions, sulfate-reducing bacteria (SRB) may therefore contribute significantly to hydrogen oxidation in these extreme environments, where sulfate is not limiting (Fishbain et al., 2003). It is therefore not surprising that several cultivation-based and culture-independent molecular phylogenetic surveys have provided evidence of a wide diversity of SRB inhabiting geothermal terrestrial hot springs (Blank et al., 2002; Ferris et al., 2003; Fishbain et al., 2003; Hugenholtz et al., 1998; Meyer-Dombard et al., 2005; Skirnisdottir et al., 2000). Most of the SRB isolated so far from terrestrial hot springs, with the exception of the crenarchaeote Caldivirga maquilingensis (Itoh et al., 1999), have been reported to oxidize hydrogen. They comprise bacterial members of (i) the genus Thermodesulfobacterium (Zeikus et al., 1983; Sonne-Hansen \& Ahring 1999), representing one of the deepest branches within the 
phylogenetic tree, (ii) the genus Thermodesulfovibrio (Henry et al. 1994; Sonne-Hansen \& Ahring 1999), belonging to the phylum 'Nitrospirae', (iii) the genus Thermodesulfobium, peripherally related to the phylum 'Nitrospirae', (iv) the genus Desulfomicrobium (Thevenieau et al., 2007), a representative of the Deltaproteobacteria, and (v) the genus Desulfotomaculum (Goorissen et al., 2003; Liu et al., 1997), belonging to the low-G $+\mathrm{C}$ Gram-positive group. Within this latter genus, only two species have been isolated from terrestrial hot springs: Desulfotomaculum luciae, isolated in Canada, and Desulfotomaculum solfataricum, isolated in Iceland.

Here, we report on the isolation of three hydrogenotrophic, thermophilic SRB originating from a terrestrial hot spring in Tunisia and belonging to the genera Thermodesulfovibrio and Desulfotomaculum. We also propose the assignment of one of these isolates to a novel species of the genus Desulfotomaculum.

Samples were collected from the Hamam Essalhine hot spring, located $10 \mathrm{~km}$ north of Fernana on the FernanaBen Mtir road in north-east Tunisia at $280 \mathrm{~m}$ elevation. The hot-spring water is discharged into the River Wad'Ellil. The water temperature at the sampling site was $73{ }^{\circ} \mathrm{C}$, the $\mathrm{pH}$ was 6.9 and the salinity was approximately $0.5 \% \mathrm{NaCl}$. The sulfate concentration in the water was $70 \mathrm{mg} \mathrm{l}^{-1}$. SRB were isolated from mixed sediment/water samples collected in sterile plastic bottles in January 2005 and kept at $4{ }^{\circ} \mathrm{C}$ until used.

The Hungate technique (Hungate, 1969) was used throughout for cultivation. The basal medium contained the following $\left(\mathrm{l}^{-1}\right.$ distilled water): $0.3 \mathrm{~g} \quad \mathrm{KH}_{2} \mathrm{PO}_{4}, 0.3 \mathrm{~g}$ $\mathrm{K}_{2} \mathrm{HPO}_{4}, 1.0 \mathrm{~g} \mathrm{NH}_{4} \mathrm{Cl}, 1.0 \mathrm{~g} \mathrm{NaCl}, 3.0 \mathrm{~g} \mathrm{Na}_{2} \mathrm{SO}_{4}, 0.1 \mathrm{~g}$ $\mathrm{KCl}, 0.1 \mathrm{~g} \mathrm{CaCl}_{2} \cdot 2 \mathrm{H}_{2} \mathrm{O}, 0.5 \mathrm{~g} \mathrm{MgCl}_{2} \cdot 6 \mathrm{H}_{2} \mathrm{O}, 0.1 \mathrm{~g}$ yeast extract (Difco), $0.5 \mathrm{~g}$ cysteine hydrochloride, $1 \mathrm{ml}$ trace mineral element solution (Widdel \& Pfennig, 1981) and $1 \mathrm{ml} 0.1 \%$ resazurin. The $\mathrm{pH}$ was adjusted to 7.2 with $10 \mathrm{M}$ $\mathrm{KOH}$. The basal medium was boiled under a stream of $\mathrm{O}_{2-}$ free $\mathrm{N}_{2}$ gas and then cooled to room temperature and $5 \mathrm{ml}$ aliquots were distributed into Hungate tubes under a stream of $\mathrm{O}_{2}$-free $\mathrm{N}_{2}$ gas. The $\mathrm{N}_{2}$ gas phase was replaced with $\mathrm{N}_{2}$ / $\mathrm{CO}_{2}(80: 20, \mathrm{v} / \mathrm{v})$ and the tubes were autoclaved for $45 \mathrm{~min}$ at $110{ }^{\circ} \mathrm{C}$. Prior to inoculation, $0.1 \mathrm{ml} 2 \% \mathrm{Na}_{2} \mathrm{~S} .9 \mathrm{H}_{2} \mathrm{O}$ and $0.1 \mathrm{ml} 10 \% \mathrm{NaHCO}_{3}$ were added.

Enrichments were performed in Hungate tubes containing $5 \mathrm{ml}$ medium and inoculated with $0.5 \mathrm{ml}$ sample. The following were used as sole substrates: $\mathrm{H}_{2}$ from a mixture of $\mathrm{H}_{2} / \mathrm{CO}_{2}[80: 20(\mathrm{v} / \mathrm{v}), 200 \mathrm{kPa}]$, acetate $(20 \mathrm{mM})$ and lactate $(20 \mathrm{mM})$. Acetate $(2 \mathrm{mM})$ was added as the carbon source in the presence of hydrogen as the electron donor. Three enrichment series were performed in the same medium before isolation. The cultures were purified by repeated use of the Hungate roll-tube method with medium solidified with $2.5 \%(\mathrm{w} / \mathrm{v})$ Noble agar (Difco) or with $0.8 \%$ Phytagel (Sigma) for cultures incubated at 55 and $70{ }^{\circ} \mathrm{C}$, respectively. Several of the colonies that developed were picked and cultured in the corresponding culture medium. The process of isolation was repeated several times until isolates were deemed to be axenic. Cultures were routinely checked by microscopy for contamination, using media containing glucose in the presence of yeast extract as the substrate.

Duplicate experiments were performed to determine the physiological conditions (temperature, $\mathrm{pH}$ and $\mathrm{NaCl}$ concentration) for optimal growth. These experiments were conducted in basal medium with the addition of lactate $(20 \mathrm{mM})$ as the electron donor and sulfate $(20 \mathrm{mM})$ as the electron acceptor. The ability to utilize organic substrates was tested in basal medium supplemented with autoclaved or filter-sterilized substrates. Butyrate, succinate, propionate, fumarate, pyruvate, lactate, acetate, malate, formate, butanol, propanol, pentanol, methanol, glycerol, ethanol, lactose, glucose, fructose and mannose were tested as energy sources, in each case at a final concentration of $20 \mathrm{mM}$. Casamino acids were tested at $0.25 \%$. The use of $\mathrm{H}_{2}(200 \mathrm{kPa})$ as an electron donor was determined in the presence and absence of acetate as a carbon source, whereas $\mathrm{CO}$ oxidation was tested at concentrations of 25,50 and $100 \%$ in the gas phase. Utilization of lactate, pyruvate, formate, ethanol, butanol, glycerol and propanol was tested in the absence of sulfate as a terminal electron acceptor. To test for electron acceptors, sodium thiosulfate (final concentration $20 \mathrm{mM})$, sodium sulfate $(20 \mathrm{mM})$, sodium sulfite $(2 \mathrm{mM})$, elemental sulfur $(2 \%, \mathrm{w} / \mathrm{v})$, sodium fumarate $(20 \mathrm{mM})$, sodium nitrate $(20 \mathrm{mM})$ and sodium nitrite $(2 \mathrm{mM})$ were added separately to the medium. Sensitivity to antibiotics was determined by transferring an exponentially growing culture into basal medium containing filter-sterilized antibiotics (penicillin, streptomycin and chloramphenicol) at 25, 50, 100, 200, 300, 500, 750 and $1000 \mu \mathrm{g} \mathrm{ml}^{-1}$.

Phase-contrast microscopy (Eclipse E600; Nikon) was used for routine examination of the cultures and to obtain photomicrographs. Light and electron microscopy were performed as described previously (Miranda-Tello et al., 2004). Growth was measured by inserting tubes directly into a model Cary 50 Scan spectrophotometer (Varian) and measuring the $\mathrm{OD}_{580}$. Sulfide was determined photometrically, as colloidal CuS, using the method of CordRuwisch (1985). The end products of organic-compound metabolism were measured as described previously (Haouari et al., 2006), using HPLC after 2 weeks incubation at optimal temperature and $\mathrm{pH}$. Cytochromes and desulfoviridin were determined as described by Postgate (1959).

The $\mathrm{G}+\mathrm{C}$ content of the DNA was determined at the Deutsche Sammlung von Mikroorganismen und Zellkulturen (DSMZ; Braunschweig, Germany), using the method of Mesbah et al. (1989). The whole-cell fatty acid composition was also determined at the DSMZ, using cell material grown under identical conditions (with lactate and sulfate as the electron donor and acceptor, respectively). 
Analysis and determination of arsenic species $[\mathrm{As}(\mathrm{V})$ and As(III)] were performed using HPLC coupled to hydride generation atomic fluorescence spectrometry. The method, described by Bohari et al. (2001), has a detection limit of $2.3 \mathrm{nM}$ for $\mathrm{As}(\mathrm{III})$ and $6.1 \mathrm{nM}$ for $\mathrm{As}(\mathrm{V})$. The total dissolved iron content was determined by using flame atomic absorption spectrometry. $\mathrm{Fe}(\mathrm{II})$ was determined using colorimetry at $510 \mathrm{~nm}$ after complexing with 1,10 phenanthrolinium chloride solution in buffered samples (pH 4.5) (Rodier et al., 1996).

The methods used for the purification and extraction of DNA and the amplification and sequencing of the $16 \mathrm{~S}$ rRNA gene were as described previously by Miranda-Tello et al. (2003), except that primer Rd1 (5'-AAGGAGGTGATCCAGCC-3') was used instead of primer R6.

The $16 \mathrm{~S}$ rRNA gene sequences of strains Lam $5^{\mathrm{T}}, \mathrm{Hbr} 5$ and Hbr7 were imported into the sequence editor BioEdit, version 5.0.9 (Hall, 1999); the base calling was examined and a contiguous consensus sequence was obtained for each isolate. A non-redundant BLASTN search (Altschul et al., 1997) of the full sequences through GenBank (Benson et al., 1999) identified their closest relatives. Sequences used in the phylogenetic analysis were obtained from the Ribosomal Database Project and GenBank and were aligned using programs provided by Ribosomal Database Project II (Maidak et al., 2001). The position of the sequences and pairwise evolutionary distances based on 1138 unambiguous nucleotides were calculated using the method of Jukes \& Cantor (1969). Dendrograms were constructed using the neighbour-joining method (Saitou \& Nei, 1987). DNADNA hybridization was performed at the DSMZ.

Enrichment cultures were performed on $\mathrm{H}_{2} / \mathrm{CO}_{2}(80: 20$, $\mathrm{v} / \mathrm{v} ; 200 \mathrm{kPa}$ ) and at atmospheric pressure at 55 and $70{ }^{\circ} \mathrm{C}$ on acetate and lactate as energy sources in the presence of sulfate as the terminal electron acceptor. Growth and sulfide production occurred in the presence of hydrogen or lactate, but not in the presence of acetate, as the electron donor. Single, brown, discus-shaped colonies $(1 \mathrm{~mm}$ in diameter) developed after 8 days incubation at $55{ }^{\circ} \mathrm{C}$ (lactate and $\mathrm{H}_{2}$ ) and $70{ }^{\circ} \mathrm{C}\left(\mathrm{H}_{2}\right)$. They were picked and serially diluted in roll-tubes before the culture was considered pure. Two strains $\left(\operatorname{Lam} 5^{\mathrm{T}}\right.$ and $\left.\mathrm{Hbr} 5\right)$ were isolated at $55{ }^{\circ} \mathrm{C}$ and one strain (Hbr7) was isolated at $70{ }^{\circ} \mathrm{C}$. The closest phylogenetic relatives of strains Lam $5{ }^{\mathrm{T}}$ and Hbr7 were the type strains of Desulfotomaculum putei (96\% similarity) and Desulfotomaculum australicum (99\% similarity), respectively, whereas the closest relative of strain Hbr5 was Thermodesulfovibrio yellowstonii (95\% similarity to the type strain). In this respect, the phylogenetic results indicated that strains $\operatorname{Lam} 5^{\mathrm{T}}$ and Hbr5 should be considered as representatives of novel species of SRB. Only strain $\mathrm{Lam}^{\mathrm{T}}$ was characterized further.

The purity of the strains was confirmed by morphological homogeneity observed under a phase-contrast microscope and by the absence of growth in liquid sulfate-free SRB medium supplemented with yeast extract $\left(1 \mathrm{~g} \mathrm{l}^{-1}\right)$ and glucose $(20 \mathrm{mM})$ under aerobic or anaerobic conditions.

Cells of strain $\operatorname{Lam} 5^{\mathrm{T}}$ were slightly curved rods, $2-5 \mu \mathrm{m}$ long and $0.5 \mu \mathrm{m}$ wide, and usually occurred singly (Fig. 1a). They were motile by means of peritrichous flagella (Fig. 1b). Endospores were observed in preparations stained with malachite green and under phase-contrast microscopy. The spores were oval and subterminal to terminal, and deformed the cells (Fig. 1a). No gas vacuoles were observed. Cells of Lam $5^{\mathrm{T}}$ stained Gram-negative. Electron micrographs of thin sections of cells revealed an atypical Gram-positive cell wall with a periodic arch-like surface layer (data not shown).

Strain Lam $5^{\mathrm{T}}$ was strictly anaerobic, growing optimally at $55{ }^{\circ} \mathrm{C}$ (range $40-60{ }^{\circ} \mathrm{C}$ ). The optimum $\mathrm{pH}$ for growth was around 7.1 (range $\mathrm{pH}$ 5.8-8.2). It did not require $\mathrm{NaCl}$ for growth. The upper $\mathrm{NaCl}$ concentration for growth was $1.5 \%(\mathrm{w} / \mathrm{v})$. The cells contained $c_{3}$-type cytochromes, but not desulfoviridin, similarly to members of the genus Desulfotomaculum. Strain $\operatorname{Lam} 5^{\mathrm{T}}$ did not require yeast extract, peptides or vitamins for growth, but $0.1 \%$ biotrypcase enhanced growth. Under optimal growth conditions, in the presence of sulfate as an electron acceptor, strain $\operatorname{Lam} 5^{\mathrm{T}}$ did not support autotrophic growth and used $\mathrm{H}_{2}$ and formate only in the presence of acetate as the carbon source. Lactate, pyruvate, ethanol, butanol,

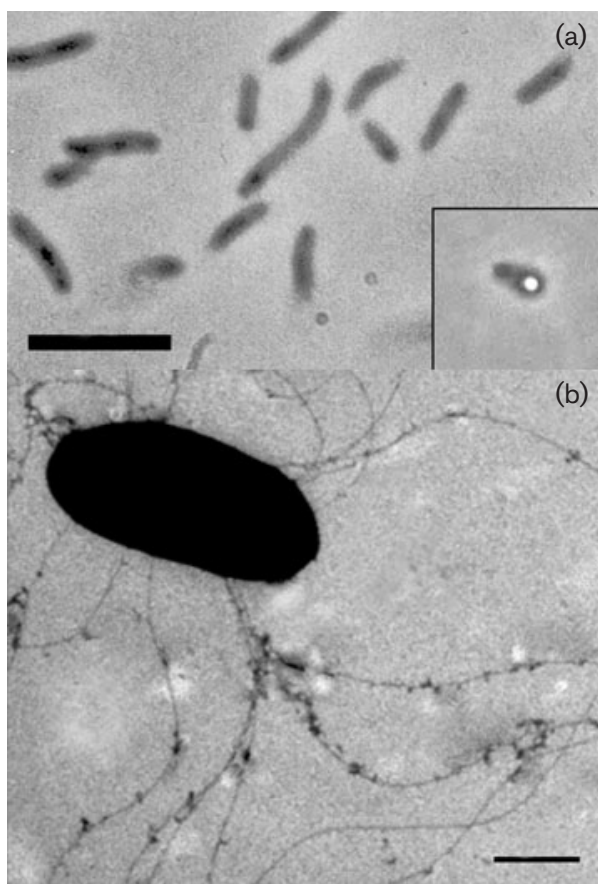

Fig. 1. Phase-contrast micrograph (a) and transmission electron photomicrograph (b) of negatively stained cell of strain Lam5 ${ }^{\top}$ grown in medium containing lactate and sulfate. Bars, $5 \mu \mathrm{m}$ (a) and $1 \mu \mathrm{m}(\mathrm{b})$. 
glycerol and propanol were also used as electron donors. The main end products resulting from lactate oxidation were acetate, $\mathrm{CO}_{2}$ and $\mathrm{H}_{2} \mathrm{~S}$. In the absence of sulfate, strain $\mathrm{Lam} 5^{\mathrm{T}}$ fermented only pyruvate, to acetate, $\mathrm{H}_{2}$ and $\mathrm{CO}_{2}$. The following compounds did not support growth of strain Lam $5^{\mathrm{T}}$ : CO, glucose, fructose, mannose, acetate, propionate, butyrate, succinate, fumarate, malate, methanol, glycerol, starch and Casamino acids. Sulfate, sulfite and thiosulfate (but not elemental sulfur, fumarate, nitrate or nitrite) served as electron acceptors in the presence of lactate as the energy and carbon source. Strain $\operatorname{Lam} 5^{\mathrm{T}}$ also reduced $\mathrm{As}(\mathrm{V})$ to $\mathrm{As}(\mathrm{III})$ and $\mathrm{Fe}(\mathrm{III})$ to $\mathrm{Fe}(\mathrm{II})$ in the presence of pyruvate as the electron donor.

Growth was inhibited by chloramphenicol $\left(25 \mu \mathrm{g} \mathrm{ml}^{-1}\right)$, streptomycin $\left(750 \mu \mathrm{g} \mathrm{ml}^{-1}\right)$ and penicillin $\left(1000 \mu \mathrm{g} \mathrm{ml}^{-1}\right)$.

Physiological characteristics of strain $\mathrm{Lam}^{\mathrm{T}}$ (e.g. the temperature optimum for growth, and for spore formation in particular) suggested that this isolate may survive, but not grow, in the Tunisian hot spring studied, as it does not grow at temperatures above $60{ }^{\circ} \mathrm{C}$. This also suggested that strain Lam $5^{\mathrm{T}}$ might play a significant ecological role only in the cooler parts of the thermal spring studied.

Analysis of the almost-complete sequence (1565 bp) of the $16 \mathrm{~S}$ rRNA gene of strain Lam $5^{\mathrm{T}}$ indicated that this novel isolate clusters with the members of the family Peptococcaceae, order Clostridiales. The phylogenetic tree (Fig. 2) showed that strain Lam $5^{\mathrm{T}}$ clustered with $D$. putei SMCC $\mathrm{W} 459^{\mathrm{T}}$, an isolate recovered from a deep terrestrial subsurface in Virginia, USA (Liu et al., 1997), with a $16 \mathrm{~S}$ rRNA gene sequence similarity of $96 \%$, thus indicating that the former strain should be assigned to a novel species of the genus Desulfotomaculum. This is confirmed by the DNA-DNA hybridization studies, which revealed a low level of relatedness $(6.5 \%)$ between the two strains. Phenotypic and genotypic characteristics of strain $\operatorname{Lam} 5^{\mathrm{T}}$, e.g. the DNA G + C content ( $46.8 \mathrm{~mol} \%)$, also indicate that it belongs to the genus Desulfotomaculum. In addition to the phylogenetic differences observed between strain Lam $5^{\mathrm{T}}$ and $D$. putei, various phenotypic differences were revealed, e.g. with regard to the use of fructose, the capacity for autotrophic growth on hydrogen (Table 1) and the temperature range for growth. In contrast to the thermophile D. putei, strain Lam $5^{\mathrm{T}}$ should be considered as a moderately thermophilic SRB. Finally, the results of a comparison between the cellular fatty acid composition of strain Lam $5^{\mathrm{T}}$ (Table 2) and that of its closest phylogenetic relative, $D$. putei, are consistent with the assignment of the isolate to a novel species of the genus Desulfotomaculum.

Members of the spore-forming genus Desulfotomaculum have been recovered from hot ecosystems on several occasions (Stackebrandt et al., 1997), suggesting a significant ecological role for these micro-organisms in such ecosystems in terms of the oxidization of hydrogen or organic compounds with the concomitant reduction of sulfate and other sulfur oxyanions to sulfide. Despite the wide distribution of thermophilic Desulfotomaculum strains within the hot biosphere, few thermophilic SRB belonging to the genus Desulfotomaculum have been isolated from terrestrial hot springs. They include D. luciae (Liu et al., 1997) and D. solfataricum (Goorissen et al., 2003). With the isolation of strain $\operatorname{Lam} 5^{\mathrm{T}}$ and also Hbr7, we have shown that Desulfotomaculum species should be considered as common inhabitants of terrestrial hot

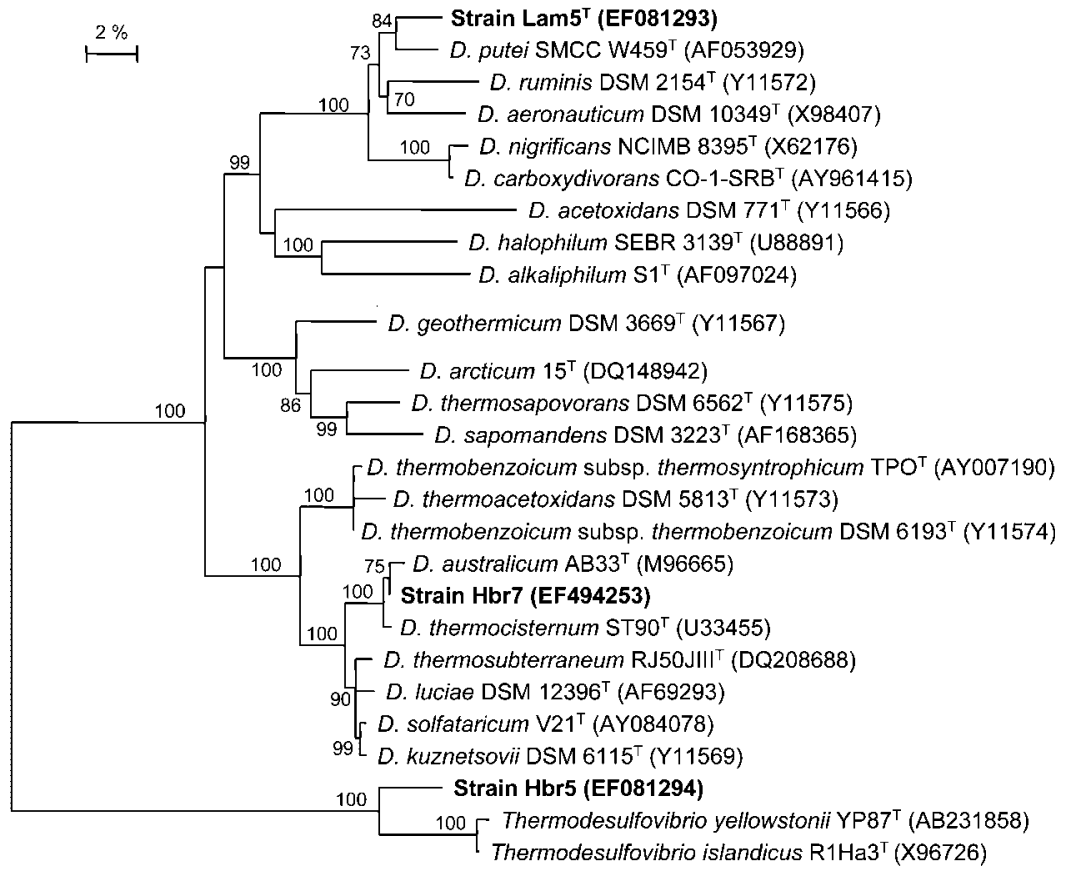

Fig. 2. Neighbour-joining phylogenetic dendrogram, based on 16S rRNA gene sequences, indicating the position of strain $\operatorname{Lam}^{\top}$ with respect to its closest relatives in the genus Desulfotomaculum. Bootstrap percentages (based on 100 resamplings) are given at nodes. Bar, $2 \%$ sequence divergence. 
Table 1. Characteristics that serve to distinguish strain Lam5 $5^{\top}$ and $D$. putei DSM $12395^{\top}$

Data for D. putei DSM $12395^{\mathrm{T}}$ were taken from Liu et al. (1997). To determine the use of electron donors, the two strains were cultivated under the same growth conditions (see basal medium above). -, No growth; +, good growth.

\begin{tabular}{|c|c|c|}
\hline Characteristic & Strain Lam $5^{\mathrm{T}}$ & D. putei DSM $12395^{\mathrm{T}}$ \\
\hline Isolation source & Terrestrial hot spring & Deep terrestrial subsurface \\
\hline Morphology & Slightly curved rods & Rods \\
\hline Cell size $(\mu \mathrm{m})$ & $1 \times 3-6$ & $1.0-1.1 \times 2-5$ \\
\hline Spore location & Terminal & Paracentral \\
\hline \multicolumn{3}{|l|}{ Temperature for growth $\left({ }^{\circ} \mathrm{C}\right)$} \\
\hline Range & $40-60$ & $40-65$ \\
\hline Optimum & 55 & 64 \\
\hline \multicolumn{3}{|l|}{$\mathrm{pH}$ for growth } \\
\hline Range & $5.8-8.20$ & $6-7.9$ \\
\hline Optimum & 7 & 7.5 \\
\hline DNA G $+C$ content $(\mathrm{mol} \%)$ & 46.8 & 47.1 \\
\hline \multicolumn{3}{|l|}{ Utilization of electron donors } \\
\hline $\mathrm{H}_{2}$ (with acetate as carbon source) & - & + \\
\hline Fructose fermentation & - & + \\
\hline
\end{tabular}

springs, as confirmed previously in a culture-independent analysis (Fishbain et al., 2003), thus emphasizing their ecological significance not only in subterrestrial ecosystems, but also in the terrestrial hot biosphere.

Table 2. Cellular fatty acid compositions (\%) of strain Lam $5^{\top}$ and D. putei DSM $12395^{\top}$

The two strains were cultivated (by the DSMZ) under the same growth conditions. ECL, Equivalent chain length; ALD, aldehyde; DMA, dimethyl acetal. In both strains, $100 \%$ of the total fatty acids were identified; - , not detected.

\begin{tabular}{|lccc|}
\hline Fatty acid & ECL & Strain Lam5 ${ }^{\mathbf{T}}$ & D. putei DSM $\mathbf{~ 1 2 3 9 5}^{\mathbf{T}}$ \\
\hline $14: 0$ & 14.0 & 0.9 & 3.0 \\
iso- $15: 0$ & 14.6 & 15.7 & 20.5 \\
anteiso-15:0 & 14.7 & 2.0 & 1.2 \\
$16: 0$ ALD & 14.9 & - & 1.1 \\
$15: 0$ DMA & 15.1 & - & 0.6 \\
iso-16:0 & 15.6 & 0.9 & - \\
$16: 1 c 7$ & 15.8 & 1.3 & 2.4 \\
$16: 1 c 9$ & 15.8 & 3.6 & 8.7 \\
$16: 1 c 11$ & 15.9 & - & 0.6 \\
$16: 0$ & 16.0 & 10.7 & 17.7 \\
$16: 1 c 9$ DMA & 16.3 & 0.9 & 2.0 \\
$16: 0$ DMA & 16.5 & 3.5 & 7.1 \\
iso-17:0 & 16.6 & 35.5 & 16.9 \\
anteiso-17:0 & 16.7 & 4.3 & 0.5 \\
$17: 0$ cyclo & 16.9 & 5.8 & 5.9 \\
$17: 0$ & 17.0 & 1.0 & - \\
iso-17:0 DMA & 17.1 & 8.5 & 8.2 \\
anteiso-17:0 & 17.2 & 0.6 & - \\
$18: 1 c 9$ & 17.8 & 0.8 & 0.7 \\
$18: 1 c 11$ & 17.8 & 2.1 & 1.7 \\
$18: 0$ & 18.0 & 1.9 & 1.2 \\
& & & \\
\hline
\end{tabular}

The identification of strain $\operatorname{Lam} 5^{\mathrm{T}}$ as a novel representative of the SRB belonging to the low- $\mathrm{G}+\mathrm{C}$ Gram-positive group is of taxonomic significance, but it is also noteworthy that our enrichments using hot-spring water samples at 55 and $70{ }^{\circ} \mathrm{C}$ have led to the isolation of hydrogenotrophic SRB $\left(\mathrm{H}_{2}\right.$ being generated geothermally from hot springs). In contrast (as in our study), acetate oxidation through sulfate-reduction activity has never been reported to occur in terrestrial hot springs. Therefore, complete oxidation, under anaerobic conditions, of organic matter (when available in these hot ecosystems) should occur as a result of alternative types of metabolism, such as methanogenesis or iron reduction (Chang et al., 2001). Finally, in contrast to Desulfosporosinus auripigmenti (formerly Desulfotomaculum auripigmentum), strain Lam $5^{\mathrm{T}}$ was shown to reduce $\mathrm{As}(\mathrm{V})$ by means of a detoxifying system rather than a respiratory one (Newman et al., 1997).

Taken together, these results emphasize the ecologically significant role that SRB, and particularly members of the genus Desulfotomaculum, may play not only in the sulfur cycle but also in the transformation of organic matter through oxidoreductive processes in hot ecosystems.

On the basis of its phenotypic, genotypic and phylogenetic characteristics, strain Lam $5^{\mathrm{T}}$ represents a novel species of the genus Desulfotomaculum, for which the name Desulfotomaculum hydrothermale sp. nov. is proposed.

\section{Description of Desulfotomaculum hydrothermale sp. nov.}

Desulfotomaculum hydrothermale (hy.dro.ther.ma'le. Gr. n. hydro water; Gr. n. thermos heat; N.L. neut. adj. hydrothermale from a hydrothermal area).

Anaerobic and moderately thermophilic. Cells are slightly curved rods, about $0.5 \mu \mathrm{m}$ wide and $2-5 \mu \mathrm{m}$ long, and 
stain Gram-negative. Oval, subterminal to terminal spores are produced that deform the cells. Cells are motile by means of peritrichous flagella. Growth occurs between 40 and $60{ }^{\circ} \mathrm{C}$ (optimally at $55{ }^{\circ} \mathrm{C}$ ). The $\mathrm{pH}$ range for growth is 5.8-8.2 (optimum $\mathrm{pH} 7.1$ ). Growth does not occur at $\mathrm{NaCl}$ concentrations above $1.5 \%(\mathrm{w} / \mathrm{v})$. Sulfate, thiosulfate and sulfite are used as electron acceptors, but elemental sulfur, fumarate, nitrate or nitrite are not used. $\mathrm{As}(\mathrm{V})$ is reduced to $\mathrm{As}(\mathrm{III})$ and $\mathrm{Fe}(\mathrm{III})$ is reduced to $\mathrm{Fe}(\mathrm{II})$. Electron donors utilized in the presence of sulfate as the electron acceptor include lactate, pyruvate, formate, ethanol, butanol, glycerol, propanol and $\mathrm{H}_{2}$. Lactate is oxidized to acetate. Pyruvate is fermented to acetate, $\mathrm{H}_{2}$ and $\mathrm{CO}_{2}$. Fructose is not used. The DNA $\mathrm{G}+\mathrm{C}$ content of the type strain is $46.8 \mathrm{~mol} \%$ (by HPLC).

The type strain, Lam $^{\mathrm{T}}\left(=\mathrm{DSM} 18033^{\mathrm{T}}=\mathrm{JCM} 13992^{\mathrm{T}}\right)$, was isolated from a terrestrial hot spring in Tunisia.

\section{Acknowledgements}

We thank Pierre Thomas for electron microscopy, and Chrystelle Bancon (Laboratoire Hydrosciences Montpellier, UMR 5569) for technical assistance and Pierre Roger for his comments on the manuscript.

\section{References}

Aguiar, P., Beveridge, T. J. \& Reysenbach, A.-L. (2004). Sulfurihydrogenibium azorense sp. nov., a thermophilic hydrogenoxidizing microaerophile from terrestrial hot springs in the Azores. Int J Syst Evol Microbiol 54, 33-39.

Altschul, S. F., Madden, T. L., Schäffer, A. A., Zhang, J., Zhang, Z., Miller, W. \& Lipman, D. J. (1997). Gapped BLAST and PSI-BLAST: a new generation of protein database search programs. Nucleic Acids Res 25, 3389-3402.

Benson, D. A., Boguski, M. S., Lipman, D. J., Ostell, J., Ouellette, B. F. F., Rapp, B. A. \& Wheeler, D. L. (1999). GenBank. Nucleic Acids Res 27, 12-17.

Blank, C. E., Cady, S. L. \& Pace, N. (2002). Microbial composition of near-boiling silica-depositing thermal springs throughout Yellowstone National Park. Appl Environ Microbiol 68, 5123-5135.

Bohari, Y., Astruc, A., Astruc, M. \& Cloud, J. (2001). Improvements of hydride generation for the speciation of arsenic in natural freshwater samples by HPLC-HG-AFS. J Anal At Spectrom 16, 774-778.

Chang, Y.-J., Peacock, A. D., Long, P., Stephen, J. R., McKinley, J. P., Macnaughton, S. J., Hussain, K. M. A., Saxton, A. M. \& White, D. C. (2001). Diversity and characterization of sulfate-reducing bacteria in groundwater at a uranium mill tailings site. Appl Environ Microbiol 67, 3149-3160.

Cord-Ruwisch, R. (1985). A quick method for the determination of dissolved and precipitated sulfides in cultures of sulfate-reducing bacteria. J Microbiol Methods 4, 33-36.

Ferris, M. J., Magnuson, T. S., Fagg, J. A., Thar, R., Kühl, M., Sheehan, K. B. \& Henson, J. M. (2003). Microbially mediated sulfide production in a thermal acidic algal mat community in Yellowstone National Park. Environ Microbiol 5, 954-960.

Fishbain, S., Dillon, J. G., Gough, H. L. \& Stahl, D. A. (2003). Linkage of high rates of sulfate reduction in Yellowstone hot springs to unique sequence types in the dissimilatory sulfate respiration pathway. Appl Environ Microbiol 69, 3663-3667.

Goorissen, H. P., Boschker, H. T. S., Stams, A. J. M. \& Hansen, T. A. (2003). Isolation of thermophilic Desulfotomaculum strains with methanol and sulfite from solfataric mud pools, and characterization of Desulfotomaculum solfataricum sp. nov. Int J Syst Evol Microbiol 53, 1223-1229.

Hall, T. A. (1999). BioEdit: a user-friendly biological sequence alignment editor and analysis program for Windows 95/98/NT. Nucleic Acids Symp Ser 41, 95-98.

Haouari, O., Fardeau, M.-L., Casalot, L., Tholozan, J.-L., Hamdi, M. \& Ollivier, B. (2006). Isolation of sulfate-reducing bacteria from Tunisian marine sediments and description of Desulfovibrio bizertensis sp. nov. Int J Syst Evol Microbiol 56, 2909-2913.

Henry, E. A., Devereux, R., Maki, J. S., Gilmour, C. C., Woese, C. R., Mandelco, L., Schauder, R., Remsen, C. C. \& Mitchell, R. (1994). Thermodesulfovibrio yellowstonii, gen. nov. and sp. nov.: its phylogenetic relationship to Thermodesulfobacterium commune and their origins deep within the bacterial domain. Arch Microbiol 161, 62-69.

Hugenholtz, P., Pitulle, C., Hershberger, K. L. \& Pace, N. R. (1998). Novel division level bacterial diversity in a Yellowstone hot spring. $J$ Bacteriol 180, 366-376.

Hungate, R. E. (1969). A roll tube method for cultivation of strict anaerobes. Methods Microbiol 3B, 117-132.

Itoh, T., Suzuki, K., Sanchez, P. C. \& Nakase, T. (1999). Caldivirga maquilingensis gen. nov., sp. nov., a new genus of rod-shaped crenarchaeote isolated from a hot spring in the Philippines. Int J Syst Bacteriol 49, 1157-1163.

Jukes, T. H. \& Cantor, C. R. (1969). Evolution of protein molecules. In Mammalian Protein Metabolism, vol. 3, pp. 21-132. Edited by H. N. Munro. New York: Academic Press.

Liu, Y., Karnauchow, T. M., Jarrell, K. F., Balkwill, D. L., Drake, G. R., Ringelberg, D., Clarno, R. \& Boone, D. R. (1997). Description of two new thermophilic Desulfotomaculum spp., Desulfotomaculum putei sp. nov., from a deep terrestrial subsurface, and Desulfotomaculum luciae sp. nov., from a hot spring. Int J Syst Bacteriol 47, 615-621.

Maidak, B. L., Cole, J. R., Lilburn, T. G., Parker, C. T., Jr, Saxman, P. R., Farris, R. J., Garrity, G. M., Olsen, G. J., Schmidt, T. M. \& Tiedje, J. M. (2001). The RDP-II (Ribosomal Database Project). Nucleic Acids Res 29, 173-174.

Mesbah, M., Premachandran, U. \& Whitman, W. B. (1989). Precise measurement of the $\mathrm{G}+\mathrm{C}$ content of deoxyribonucleic acid by highperformance liquid chromatography. Int J Syst Bacteriol 39, 159-167.

Meyer-Dombard, D. R., Shock, E. L. \& Amend, J. P. (2005). Archaeal and bacterial communities in geochemically diverse hot springs of Yellowstone National Park, USA. Geobiology 3, 211-227.

Miranda-Tello, E., Fardeau, M.-L., Fernández, L., Ramírez, F., Cayol, J.-L., Thomas, P., Garcia, J.-L. \& Ollivier, B. (2003). Desulfovibrio capillatus sp. nov., a novel sulfate-reducing bacterium isolated from an oil field separator located in the Gulf of Mexico. Anaerobe 9, 97-103.

Miranda-Tello, E., Fardeau, M.-L., Thomas, P., Ramírez, F., Casalot, L., Cayol, J.-L., Garcia, J.-L. \& Ollivier, B. (2004). Petrotoga mexicana sp. nov., a novel thermophilic, anaerobic and xylanolytic bacterium isolated from an oil-producing well in the Gulf of Mexico. Int J Syst Evol Microbiol 54, 169-174.

Newman, D. K., Kennedy, E. K., Coates, J. D., Ahmann, D., Ellis, D. J., Lovley, D. \& Morel, F. M. M. (1997). Dissimilatory arsenate and sulfate reduction in Desulfotomaculum auripigmentum sp. nov. Arch Microbiol 168, 380-388.

Postgate, J. R. (1959). A diagnostic reaction of Desulphovibrio desulphuricans. Nature 183, 481-482. 
Reysenbach, A.-L. \& Shock, E. (2002). Merging genomes with geochemistry in hydrothermal ecosystems. Science 296, 1077-1082.

Reysenbach, A.-L., Wickham, G. S. \& Pace, N. R. (1994). Phylogenetic analysis of the hyperthermophilic pink filament community in Octopus Spring, Yellowstone National Park. Appl Environ Microbiol 60, 2113-2119.

Rodier, J., Broutin, J. P., Chambon, P., Champsaur, H. \& Rodi, L. (1996). L'Analyse de l'Eau. Paris: Dunod (in French).

Saitou, N. \& Nei, M. (1987). The neighbor-joining method: a new method for reconstructing phylogenetic trees. Mol Biol Evol 4, 406-425.

Skirnisdottir, S., Hreggvidsson, O. G., Hjörleifsdottir, S., Marteinsson, V. T., Petursdottir, S. K., Holst, O. \& Kristjansson, J. K. (2000). Influence of sulfide and temperature on species composition and community structure of hot spring microbial mats. Appl Environ Microbiol 66, 2835-2841.

Sonne-Hansen, J. \& Ahring, B. K. (1999). Thermodesulfobacterium hveragerdense sp. nov., and Thermodesulfovibrio islandicus sp. nov., two thermophilic sulfate reducing bacteria isolated from a Icelandic hot spring. Syst Appl Microbiol 22, 559-564.
Stackebrandt, E., Sproer, C., Rainey, F. A., Burghardt, J., Päuker, O. \& Hippe, H. (1997). Phylogenetic analysis of the genus Desulfotomaculum: evidence for the misclassification of Desulfotomaculum guttoideum and description of Desulfotomaculum orientis as Desulfosporosinus orientis gen. nov., comb. nov. Int J Syst Bacteriol 47, 1134-1139.

Thevenieau, F., Fardeau, M.-L., Ollivier, B., Joulian, C. \& Baena, S. (2007). Desulfomicrobium thermophilum sp. nov., a novel thermophilic sulphate-reducing bacterium isolated from a terrestrial hot spring in Colombia. Extremophiles 11, 295-303.

Widdel, F. \& Pfennig, N. (1981). Studies on dissimilatory sulfatereducing bacteria that decompose fatty acids. I. Isolation of new sulfate-reducing bacteria enriched with acetate from saline environments. Description of Desulfobacter postgatei gen. nov., sp. nov. Arch Microbiol 129, 395-400.

Zeikus, J. G., Dawson, M. A., Thompson, T. E., Ingvorsen, K. \& Hatchikian, E. C. (1983). Microbial ecology of volcanic sulfidogenesis: isolation and characterization of Thermodesulfotobacterium commune gen. nov. and sp. nov. J Gen Microbiol 129, 1159-1169. 